\title{
Mangromicins A and B: structure and antitrypanosomal activity of two new cyclopentadecane compounds from Lechevalieria aerocolonigenes K10-0216
}

\author{
Takuji Nakashima ${ }^{1}$, Masato Iwatsuki ${ }^{2,3}$, Junya Ochiai ${ }^{3}$, Yoshiyuki Kamiya ${ }^{3}$, Kenichiro Nagai ${ }^{4}$, \\ Atsuko Matsumoto ${ }^{2,3}$, Aki Ishiyama ${ }^{2}$, Kazuhiko Otoguro ${ }^{2}$, Kazuro Shiomi ${ }^{2,3}$, Yōko Takahashi ${ }^{2,3}$ \\ and Satoshi Ōmura ${ }^{2}$
}

Two new cyclopentadecane antibiotics, named mangromicins $A$ and $B$, were separated out from the culture broth of Lechevalieria aerocolonigenes K10-0216 by Diaion HP-20, silica gel and ODS column chromatography, and were finally purified by HPLC. The chemical structures of the two novel compounds were elucidated by instrumental analyses, including various NMR, MS and X-ray crystallography. Mangromicins A and B consist of cyclopentadecane skeletons with a tetrahydrofuran unit and a 5,6-dihydro-4-hydroxy-2-pyrone moiety. Mangromicins $A$ and $B$ showed in vitro antitrypanosomal activity with $\mathrm{IC}_{50}$ values of 2.4 and $43.4 \mu \mathrm{g} \mathrm{ml}^{-1}$, respectively. The $\mathrm{IC}_{50}$ values of both compounds were lower than those of cytotoxicity against MRC-5 human fetal lung fibroblast cells.

The Journal of Antibiotics (2014) 67, 253-260; doi:10.1038/ja.2013.129; published online 11 December 2013

Keywords: antitrypanosomal activity; Lechevalieria aerocolonigenes; mangromicins; mangrove sediment; physicochemical screening

\section{INTRODUCTION}

The myriad and complex biosynthetic routes involved in natural product chemistry result in almost limitless chemical diversity with numerous chemicals exhibiting a wide range of useful bioactivity. Natural products arising from microorganisms have played a pivotal role in drug discovery for more than a century. ${ }^{1}$ Actinomycetes have long been recognized as prolific producers of useful bioactive metabolites that have demonstrated a broad spectrum of bioactivity, ${ }^{2,3}$ and they possess $>20$ secondary metabolic biosynthesis gene clusters. ${ }^{4-7}$ However, the expression of secondary metabolite genes is remarkably influenced by environmental factors; such as, temperature, aeration, cultivation time and nutrients. ${ }^{8,9}$ Although it is widely believed that many more useful compounds will be discovered from the secondary metabolites of actinomycetes, as long as culture conditions are optimized, it is getting increasingly difficult to discover and develop new natural product-based therapeutic drugs for clinical studies. ${ }^{10}$

We have a long history of undertaking biological screening programs to try and find new useful compounds from microorganisms. However, in these biological screening programs, in cases where the production of metabolites only creates minute amounts of a compound or where specific biological assays are unsuitable or nonexistent, it is possible to miss or overlook potential and valuable compounds. Fortunately, chemical screening systems compliment biological screening systems and allow for detection of even minute amounts of any compound. Secondary metabolites in a fermentation broth can be detected by analytical method (e.g. HPLC-MS) or color reaction (e.g. Dragendorff's reagent). Even if we cannot identify useful biological activities of new compounds using currently available biological assays, it is possible that any pure compound can be tested at a later date and may be developed as a potentially useful drug or drug lead in the future. As an example, staurosporine was discovered from secondary metabolites of Streptomyces sp. AM-2282 ${ }^{11}$ (present strain name is Lentzea albida $a^{12}$ via Saccharothrix aerocolonigenes subsp. staurosporeus ${ }^{13}$ ) in 1977 while screening to detect alkaloids using Dragendorff's reagent. It was originally found to exhibit antifungal properties. ${ }^{11}$ In 1986 , nine years after discovery, staurosporine was found to be a nanomolar inhibitor of protein kinases, through the prevention of ATP binding to the kinase. ${ }^{14,15}$ The interesting biological activity stimulated exploratory

${ }^{1}$ Research Organization for Infection Control Sciences, Kitasato University, Tokyo, Japan; ${ }^{2}$ Kitasato Institute for Life Sciences, Kitasato University, Tokyo, Japan; ${ }^{3}$ Graduate School of Infection Control Sciences, Kitasato University, Tokyo, Japan and ${ }^{4}$ Graduate School of Pharmaceutical Sciences, Kitasato University, Tokyo, Japan Correspondence: Dr T Nakashima, Research Organization for Infection Control Sciences, Kitasato University, 5-9-1 Shirokane, Minato-ku, Tokyo 108-8641, Japan. E-mail: takuji@lisci.kitasato-u.ac.jp

or Professor Y Takahashi, Kitasato Institute for Life Sciences, Kitasato University, 5-9-1 Shirokane, Minato-ku, Tokyo 108-8641, Japan.

E-mail: ytakaha@lisci.kitasato-u.ac.jp

Received 17 August 2013; revised 28 September 2013; accepted 25 October 2013; published online 11 December 2013 
research on staurosporine derivatives and selective protein kinase inhibitors by many laboratories and pharmaceutical companies, eventually resulting in the development of imatinib, ${ }^{16}$ an anticancer agent that entered human clinical trials for chronic myelogenous leukemia in 1998, being approved for use in the United States in $2001 .{ }^{17}$

We have paid attention to the isolation and purification of novel compounds from cultured broths of microorganisms using an approach based on the physicochemical properties of compounds, using HPLC-UV detection (LC/UV), -MS (LC/MS) system and color reaction. Peaks originating from unknown compounds can be identified using existing databases, such as the Dictionary of Natural Products (http://dnp.chemnetbase.com/), as well as in-house databases. We refer to this method as physicochemical screening. The ongoing physicochemical screening program has recently discovered two new cyclopentadecane compounds with a 5,6-dihydro-4-hydroxy2-pyrone ring and a tetrahydrofuran unit, which have been named mangromicins A (1) and B (2). ${ }^{18,19}$ The compounds were discovered in a cultured broth of actinomycete strain K10-0216, which was isolated from a mangrove sediment sample collected on Iriomote Island, Japan. The producing organism was subsequently identified to be the rare actinomycete, Lechevalieria aerocolonigenes. Mangromicins A (1) and B (2) exhibited antitrypanosomal activity.

\section{RESULTS AND DISCUSSION}

Taxonomy of the producing strain, $L$. aerocolonigenes K10-0216 Strain K10-0216 was isolated from a mangrove sediment sample collected on Iriomote Island, Japan. The strain grew well on yeast extract-malt extract agar, inorganic salts-starch agar, oatmeal agar and others, but weakly on glucose-asparagine agar, tyrosine agar and glucose-nitrate agar. The colony color was yellowish brown. Extremely sparse white aerial mycelia were only produced on inorganic salts-starch agar and formed clumps of interwoven hyphae (Figure 1). No soluble pigment was produced. Whole-cell hydrolysates contained meso-diaminopimelic acid. The predominant menaquinone of the strain was MK-9 $\left(\mathrm{H}_{4}\right)$. The $16 \mathrm{~S}$ rRNA gene sequence (1394 nucleotides) was determined and analyzed using the EzTaxon-e database (http://eztaxon-e.ezbiocloud.net/) and was closely related to L. aerocolonigenes ISP $5034^{\mathrm{T}}$ (AB020030, similarity: 99.8\%). These results showed that this strain belonged to genus Lechevalieria. ${ }^{20}$ The phylogenetic tree also supported the result (Supplementary Figure $\mathrm{S} 1)$. On the basis of the morphological and cultural properties and $16 \mathrm{~S}$ rRNA gene sequence analyses, strain K10-0216 is identified with L. aerocolonigenes.

Isolation of mangromicins A (1) and B (2)

Isolation of mangromicins was guided by physicochemical screening using LC/UV and LC/MS equipments. The procedure for isolation of compounds 1 and 2 is summarized in Scheme 1. The whole culture broth (15l) was centrifuged to separate the mycelium and supernatant. The supernatant was passed through a column of Diaion HP-20 (100 i.d. $\times 250 \mathrm{~mm}$; Mitsubishi Chemical, Tokyo, Japan) previously equilibrated with water. After washing with water and $40 \%$ $\mathrm{MeOH}$, the fraction containing the mangromicins was eluted with $100 \% \mathrm{MeOH}$. The whole eluate was concentrated in vacuo to dryness, yielding $5.6 \mathrm{~g}$ of material. This material was subjected to column chromatography on silica gel FL100D (60 i.d. $\times 200 \mathrm{~mm}$; Fuji Silysia Chemical, Aichi, Japan), eluted with a stepwise gradient of $\mathrm{CHCl}_{3}$ $\mathrm{MeOH}(100: 0,100: 1,50: 1,10: 1,1: 1$ and $0: 100(\mathrm{v} / \mathrm{v}))$, to give six fractions. The eluate fractions (100:1 and 50:1 fractions) were combined and concentrated to yield $780 \mathrm{mg}$. The material was applied
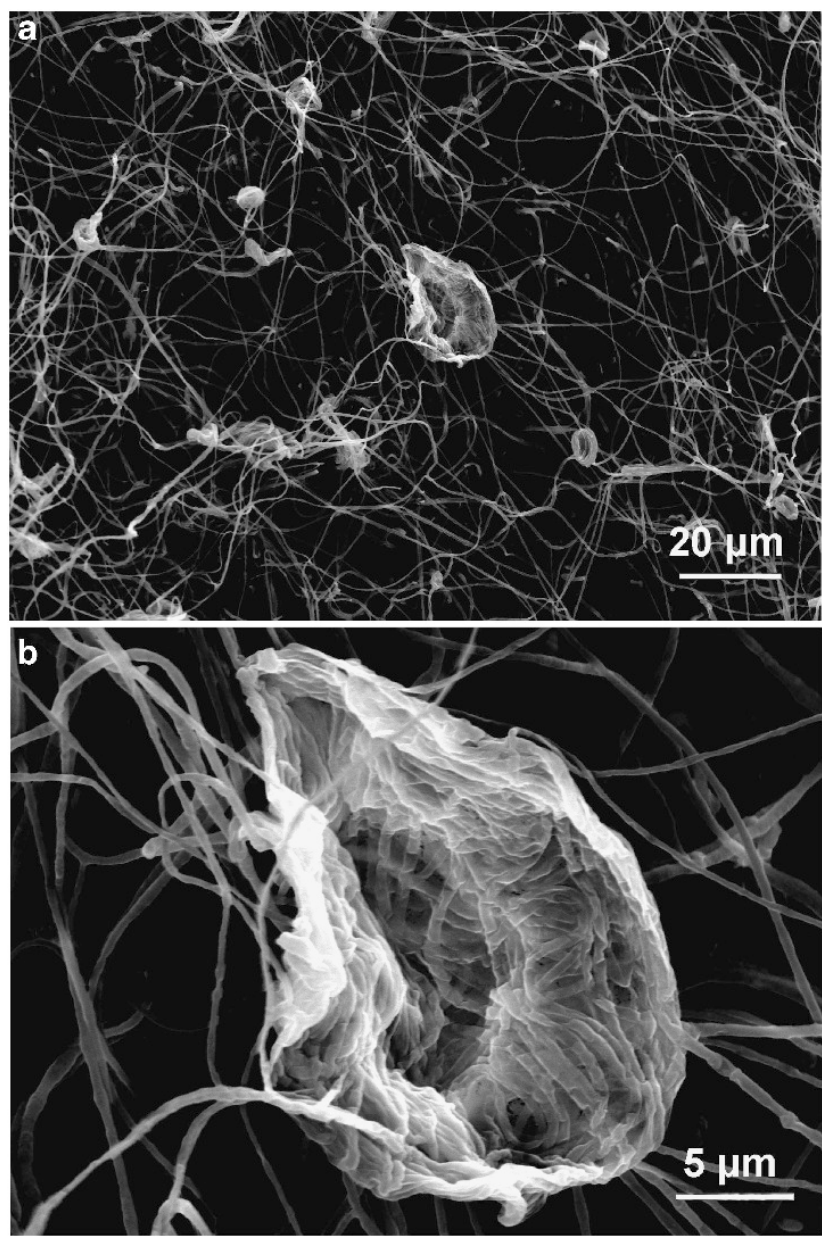

Figure 1 Scanning electron micrograph of aerial mycelia of Lechevalieria aerocolonigenes K10-0216 grown on (a) and (b) inorganic salts-starch agar at $27^{\circ} \mathrm{C}$ for 4 weeks.

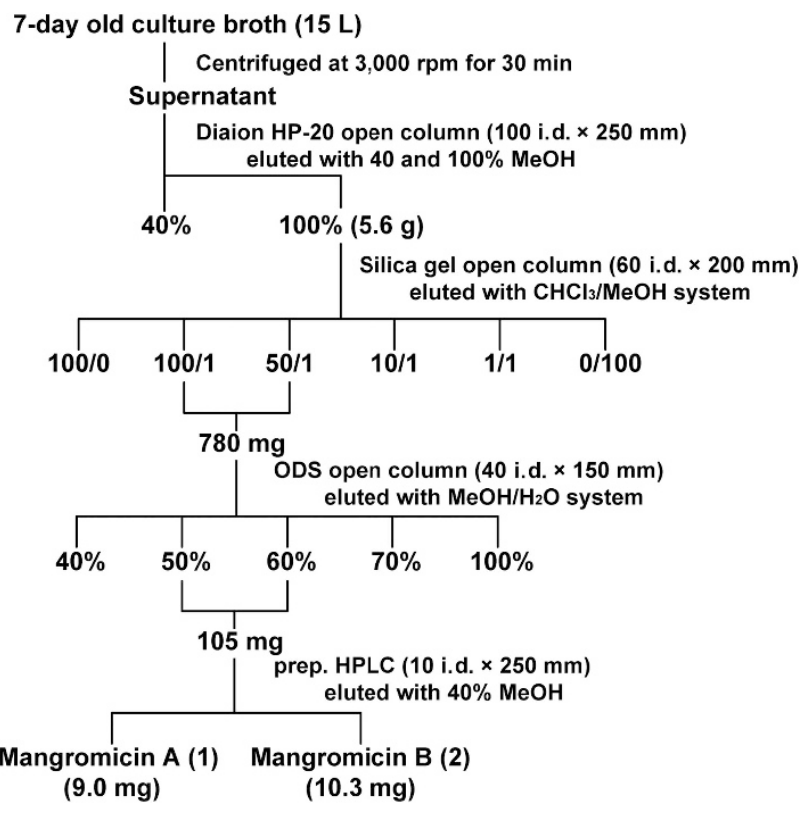

Scheme 1 Purification of mangromicins A (1) and B (2). 
on an ODS column (40 i.d. $\times 150 \mathrm{~mm}$; Senshu Scientific, Tokyo, Japan) previously equilibrated with water. After washing with water and $40 \% \mathrm{MeOH}$, the fractions containing mangromicins were eluted with 50 and $60 \% \mathrm{MeOH}$ and concentrated in vacuo. The eluate fractions $(105 \mathrm{mg})$ were dissolved in a small amount of $\mathrm{MeOH}$ and purified by HPLC on an Inertsil ODS-4 column $(10$ i.d. $\times 250 \mathrm{~mm}$; GL Sciences) with $40 \% \mathrm{MeOH}$ at $4.7 \mathrm{ml} \mathrm{min}^{-1}$ and subsequently

Table 1 Physico-chemical properties of mangromicins A (1) and B (2)

\begin{tabular}{|c|c|c|}
\hline & Mangromicin A (1) & Mangromicin B (2) \\
\hline Appearance & $\begin{array}{l}\text { Pale yellow or } \\
\text { colorless needle }\end{array}$ & Pale yellow \\
\hline Molecular formula & $\mathrm{C}_{22} \mathrm{H}_{34} \mathrm{O}_{7}$ & $\mathrm{C}_{22} \mathrm{H}_{32} \mathrm{O}_{6}$ \\
\hline MW & 410 & 392 \\
\hline \multicolumn{3}{|l|}{$E S I-M S(m / z)$} \\
\hline Calcd. & $411.2383\left(\right.$ for $\mathrm{C}_{22} \mathrm{H}_{35} \mathrm{O}_{7}$ ) & 393.2277 (for $\mathrm{C}_{22} \mathrm{H}_{33} \mathrm{O}_{6}$ ) \\
\hline Found & $411.2377[\mathrm{M}+\mathrm{H}]^{+}$ & $393.2271[\mathrm{M}+\mathrm{H}]^{+}$ \\
\hline$[\alpha]_{D}^{25.3}(c 0.1, \mathrm{MeOH})$ & -13.56 & -24.08 \\
\hline UV $\lambda_{\max }(\mathrm{MeOH}) \mathrm{nm}$ & $251(2747)$ & $236(8036)$ \\
\hline $\mathrm{IR} v_{\max }{ }^{\mathrm{KBr}} \mathrm{cm}^{-1}$ & 3440,1637 & 3450,1672 \\
\hline \multicolumn{3}{|l|}{ Solubility } \\
\hline Soluble & $\mathrm{MeOH}, \mathrm{EtOH}$ & $\mathrm{MeOH}, \mathrm{EtOH}$ \\
\hline Insoluble & Benzene, $\mathrm{CHCl}_{3}$ & Benzene, $\mathrm{CHCl}_{3}$ \\
\hline
\end{tabular}

detected at UV $254 \mathrm{~nm}$. The yields of mangromicins A (1) and B (2) were 9.0 and $10.3 \mathrm{mg}$, respectively.

Physico-chemical properties of mangromicins A (1) and B (2) The physico-chemical properties of compounds $\mathbf{1}$ and $\mathbf{2}$ are summarized in Table 1. They are readily soluble in $\mathrm{MeOH}$ and $\mathrm{EtOH}$ but not benzene and $\mathrm{CHCl}_{3}$. Compounds $\mathbf{1}$ and $\mathbf{2}$ showed absorption maxima at 251 and $236 \mathrm{~nm}$ in UV spectra, respectively. The IR absorption at 3440 and $1637 \mathrm{~cm}^{-1}$ in 1 , and 3450 and $1672 \mathrm{~cm}^{-1}$ in 2 suggested the presence of hydroxyl and carbonyl groups, respectively. The similarity in physico-chemical properties strongly suggested that these two compounds are structurally related.

\section{Structure elucidation of mangromicin A (1)}

Mangromicin A (1) was obtained as a pale yellow powder or a colorless needle crystal determined to have the molecular formula of $\mathrm{C}_{22} \mathrm{H}_{34} \mathrm{O}_{7}$ by HR-ESI-MS $[\mathrm{M}+\mathrm{H}]^{+} \mathrm{m} / z \quad 411.2377$ (calcd. for $\mathrm{C}_{22} \mathrm{H}_{35} \mathrm{O}_{7}, 411.2383$ ) and NMR spectral data. The $1 \mathrm{D}$ and $2 \mathrm{D}$ NMR spectra of 1 were mainly obtained in $\mathrm{CD}_{3} \mathrm{OD}$. As some broadening signals were observed in $\mathrm{CD}_{3} \mathrm{OD}$, the ${ }^{1} \mathrm{H}$ and ${ }^{13} \mathrm{C}$ spectra of 1 in DMSO- $d_{6}$ were also measured at $80^{\circ} \mathrm{C}$ to yield sharp signals.

The ${ }^{1} \mathrm{H}$ and ${ }^{13} \mathrm{C}$ NMR spectral data of 1 are listed in Table 2 . The ${ }^{1} \mathrm{H}$ NMR data indicated the presence of four oxygenated $s p^{3}$ methines, three $s p^{3}$ methine protons containing two methine ones coupled to methyl groups, six methylenes, one primary methyl, two secondary methyls and one tertiary methyl. The ${ }^{13} \mathrm{C}$ NMR spectrum showed the resonances of 22 carbons, which were classified into two olefinic carbons, two carbonyl carbons at $\delta_{\mathrm{c}} 169.3$ and 208.8, one oxygenated

Table 2 NMR spectroscopic data $\left(\mathrm{CD}_{3} \mathrm{OD}, 400 \mathrm{MHz}\right)$ for mangromicin A (1)

\begin{tabular}{|c|c|c|c|}
\hline Position & $\delta_{C}$, Mult & $\delta_{H}$ (int., mult., J in $\mathrm{Hz}$ ) & $H M B C$ \\
\hline 1 & 169.3, C & & \\
\hline 2 & $103.5, \mathrm{C}$ & & \\
\hline 3 & $167.9, \mathrm{C}$ & & \\
\hline 4 & $44.4, \mathrm{CH}$ & $2.12(1 \mathrm{H}, \mathrm{t}, 7.0)$ & $\mathrm{C}-2, \mathrm{C}-3, \mathrm{C}-5, \mathrm{C}-6, \mathrm{C}-1^{\prime}, \mathrm{C}-2^{\prime}$ \\
\hline 5 & $73.8, \mathrm{CH}$ & $4.73(1 \mathrm{H}, \mathrm{dd}, 11.5,1.8)$ & $\mathrm{C}-1, \mathrm{C}-3, \mathrm{C}-4, \mathrm{C}-6, \mathrm{C}-7, \mathrm{C}-1^{\prime}$ \\
\hline $6 a$ & $44.4, \mathrm{CH}_{2}$ & $2.50(1 \mathrm{H}, \mathrm{m})$ & C-5, C-7 \\
\hline $6 b$ & & $4.54(1 \mathrm{H}, \mathrm{dd}, 11.5,18.9)$ & \\
\hline 7 & $208.8, C$ & & \\
\hline 8 & $52.7, \mathrm{CH}$ & $2.75(1 \mathrm{H}, \mathrm{qd}, 7.1,1.3)$ & $\mathrm{C}-7, \mathrm{C}-9, \mathrm{C}-10, \mathrm{C}-8-\mathrm{Me}$ \\
\hline 9 & $73.0, \mathrm{CH}$ & $4.29(1 \mathrm{H}, \mathrm{dd}, 8.4,1.3)$ & C-8, C-10, C-8-Me \\
\hline 10 & $72.3, \mathrm{CH}$ & $3.34(1 \mathrm{H}, \mathrm{d}, 8.4)$ & C-8, C-9, C-11, C-12 \\
\hline 11 & $80.3, \mathrm{CH}$ & $3.19(1 \mathrm{H}, \mathrm{d}, 8.0)$ & C-14 \\
\hline 12 & $37.3, \mathrm{CH}$ & $2.55(1 \mathrm{H}, \mathrm{m})$ & C-10, C-11, C-13, C-12-Me \\
\hline $13 a$ & $48.9, \mathrm{CH}_{2}$ & $1.62(1 \mathrm{H}, \mathrm{m})$ & $\mathrm{C}-11, \mathrm{C}-12, \mathrm{C}-14, \mathrm{C}-15, \mathrm{C}-12-\mathrm{Me}, \mathrm{C}-14-\mathrm{Me}$ \\
\hline $13 b$ & & $1.85(1 \mathrm{H}, \mathrm{dd}, 11.9,11.9)$ & \\
\hline 14 & $85.0, \mathrm{C}$ & & \\
\hline $15 a$ & $37.4, \mathrm{CH}_{2}$ & $1.27(1 \mathrm{H}, \mathrm{ddd}, 14.3,3.6,3.5)$ & C-2, C-13, C-14, C-16, C-14-Me \\
\hline $15 b$ & & $2.43(1 \mathrm{H}, \mathrm{ddd}, 14.3,13.6,3.8)$ & \\
\hline $16 a$ & $19.3, \mathrm{CH}_{2}$ & $2.05(1 \mathrm{H}, \mathrm{ddd}, 15.4,13.6,3.8)$ & C-1, C-2, C-3, C-14, C-15 \\
\hline $16 \mathrm{~b}$ & & $2.86(1 \mathrm{H}, \mathrm{ddd}, 15.4,13.6,3.5)$ & \\
\hline $1^{\prime}$ & $34.6, \mathrm{CH}_{2}$ & $1.59(2 \mathrm{H}, \mathrm{m})$ & $\mathrm{C}-3, \mathrm{C}-4, \mathrm{C}-5, \mathrm{C}-2^{\prime}, \mathrm{C}-3^{\prime}$ \\
\hline $2^{\prime} \mathrm{a}$ & $21.3, \mathrm{CH}_{2}$ & $1.40(1 \mathrm{H}, \mathrm{m})$ & $\mathrm{C}-4, \mathrm{C}-1^{\prime}, \mathrm{C}-3^{\prime}$ \\
\hline $2^{\prime} b$ & & $1.52(1 \mathrm{H}, \mathrm{m})$ & \\
\hline $3^{\prime}(\mathrm{Me})$ & $14.4, \mathrm{CH}_{3}$ & $0.95(3 \mathrm{H}, \mathrm{t}, 7.1)$ & $\mathrm{C}-1^{\prime}, \mathrm{C}-2^{\prime}$ \\
\hline 8-Me & $8.5, \mathrm{CH}_{3}$ & $1.03(3 \mathrm{H}, \mathrm{d}, 7.1)$ & $\mathrm{C}-7, \mathrm{C}-8, \mathrm{C}-9$ \\
\hline 12-Me & $13.7, \mathrm{CH}_{3}$ & $1.06(3 \mathrm{H}, \mathrm{d}, 7.1)$ & $\mathrm{C}-11, \mathrm{C}-12, \mathrm{C}-13$ \\
\hline 14-Me & $24.7, \mathrm{CH}_{3}$ & $1.35(3 \mathrm{H}, \mathrm{s})$ & C-13, C-14, C-15 \\
\hline
\end{tabular}


$s p^{3}$ quaternary carbon, four oxygenated $s p^{3}$ methine carbons, three $s p^{3}$ methine carbons, six $s p^{3}$ methylene carbons and four methyl carbons by HSQC spectra. The ${ }^{1} \mathrm{H}-{ }^{1} \mathrm{H}$ COSY indicated the presence of five partial structures: (a) C-5/C-6; (b) C-9/C-10; (c) C-11/C-13 and C-12/C-12-Me; (d) C-8/C-8-Me; and (e) C-4/C-3' as shown in Figure 2. Analysis of HMBC data confirmed the presence of a 5,6dihydro-4-hydroxy-2-pyrone moiety based on correlations from $\mathrm{H}-4$ to C-2, C-3, C-5 and C-6; from H-5 to C-1, C-3, C-4 and C-1' ; from $\mathrm{H}_{2}-15$ to $\mathrm{C}-2$ and $\mathrm{C}-16$; and from $\mathrm{H}_{2}-16$ to C-1, C-2, C-3 and C-15. The HMBC correlations from $\mathrm{H}-4$ to $\mathrm{C}-1^{\prime}$ and $\mathrm{C}-2^{\prime}$; from $\mathrm{H}-5$ to C-1'; from $\mathrm{H}_{2}-1^{\prime}$ to C-3, C-4, C-5, C-2' and C-3'; from $\mathrm{H}_{2}-2^{\prime}$ to C-4, $\mathrm{C}-1^{\prime}$ and $\mathrm{C}-3^{\prime}$; and from $\mathrm{H}_{3}-3^{\prime}$ to $\mathrm{C}-1^{\prime}$ and $\mathrm{C}-2^{\prime}$ confirmed an $n$-propyl group linked to the $\mathrm{C}-4$ position. A tetrahydrofuran unit was identified, based on HMBC correlations from $\mathrm{H}-11$ to $\mathrm{C}-14$, from $\mathrm{H}-12$ to $\mathrm{C}-11$ and $\mathrm{C}-13$ and from $\mathrm{H}_{2}-13$ to $\mathrm{C}-11, \mathrm{C}-12$ and $\mathrm{C}-14$. Moreover, the correlations from $\mathrm{H}-12$ to C-12-Me; from $\mathrm{H}_{2}-13$ to C-12-Me and C-14-Me; from $\mathrm{H}_{2}-16$ to $\mathrm{C}-14$; from $\mathrm{H}_{2}-15$ to $\mathrm{C}-13$, C-14 and C-14-Me; from $\mathrm{H}_{3}-12-\mathrm{Me}$ to $\mathrm{C}-11, \mathrm{C}-12$ and $\mathrm{C}-13$; and from $\mathrm{H}_{3}-14-\mathrm{Me}$ to $\mathrm{C}-13, \mathrm{C}-14$ and $\mathrm{C}-15$ confirmed a secondary methyl and a tertiary methyl linked to $\mathrm{C}-12$ and $\mathrm{C}-14$ positions, respectively. These HMBC correlations also showed that 5,6-dihydro4-hydroxy-2-pyrone moiety and tetrahydrofuran unit were connected by ethylene bond. Finally, the cyclopentadecane ring was confirmed by the HMBC correlations from $\mathrm{H}-5$ to $\mathrm{C}-6$ and C-7; from $\mathrm{H}_{2}-6$ to C-5 and C-7; from $\mathrm{H}-8$ to $\mathrm{C}-7, \mathrm{C}-9, \mathrm{C}-10$ and $\mathrm{C}-8-\mathrm{Me}$; from $\mathrm{H}-9$ to $\mathrm{C}-8$, C-10 and C-8-Me; from $\mathrm{H}-10$ to C-8, C-9, C-11 and C-12; from $\mathrm{H}_{3}-$ 8-Me to C-7, C-8 and C-9; and from $\mathrm{H}-12$ to C-10. Therefore, the planer structure of 1 was elucidated as shown in Figure 2, and it was designated as mangromicin A.

The relative configuration of 1 was estimated by ${ }^{1} \mathrm{H}-{ }^{1} \mathrm{H}$ coupling constant analysis, differential NOE and ROESY experiments
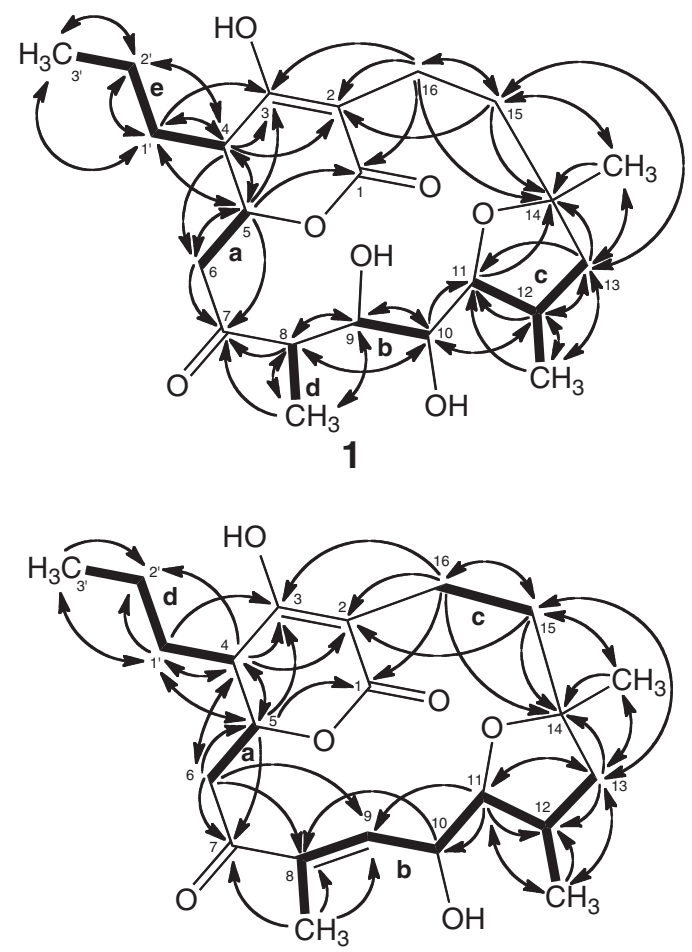

2

Figure $2{ }^{1} \mathrm{H}-{ }^{1} \mathrm{H}$ COSY (bold) and selected HMBC (arrow) correlations of mangromicins $A(1)$ and $B(2)$.
(Figure 3). The ROESY correlations were observed between $\mathrm{H}-13 \mathrm{~b} /$ $\mathrm{H}_{3}-12-\mathrm{Me}$ and $\mathrm{H}-13 \mathrm{~b} / \mathrm{H}_{3}-14-\mathrm{Me}$. These results indicate that $\mathrm{H}_{3}-14-$ Me and $\mathrm{H}_{3}-12-\mathrm{Me}$ are located on the identical face of tetrahydrofuran unit. Moreover, the ROESY correlations were observed between $\mathrm{H}-6 \mathrm{~b} /$ $\mathrm{H}-9, \mathrm{H}_{3}-8-\mathrm{Me} / \mathrm{H}-10$ and $\mathrm{H}-10 / \mathrm{H}_{3}-12-\mathrm{Me}$, and NOE correlation at $\mathrm{H}-11 / \mathrm{H}-12$. In addition, the coupling constants were observed between $\mathrm{H}-8$ and $\mathrm{H}-9(1.3 \mathrm{~Hz}), \mathrm{H}-9$ and $\mathrm{H}-10(8.4 \mathrm{~Hz})$ and $\mathrm{H}-10$ and $\mathrm{H}-11(0 \mathrm{~Hz})$. Therefore, the relative configuration from $\mathrm{C}-8$ to C-14 in 1 was determined as shown in Figure 3. Finally, the ROESY correlations were observed between $\mathrm{H}-4$ and $\mathrm{H}-6 \mathrm{a}$, and no coupling between $\mathrm{H}-4$ and H-5. These results reveal that $n$-propyl at C-4 and methylene at C-6 bound to 5,6-dihydro-4-hydroxy-2-pyrone moiety is located on the opposite surface. Therefore, the relative configuration of 1 was proposed as shown in Figure 3.

The proposed relative configuration of $\mathbf{1}$ was confirmed by X-ray analysis of a single crystal (Figure 4). Final refinement of the data resulted in a Flack parameter -0.1 (3), which did not allow determination of its absolute configuration (CCDC 947034 contains the supplementary crystallographic data for compound $\mathbf{1}$. These data can be obtained free of charge from The Cambridge Crystallographic Data Centre via www.ccdc.cam.ac.uk/data_request/cif.) These results suggested that 1 has the relative configuration of $4 R^{\star}, 5 R^{\star}, 8 R^{\star}, 9 S^{\star}$, $10 R^{\star}, 11 R^{\star}, 12 S^{\star}$ and $14 S^{\star}$ (Figure 5).
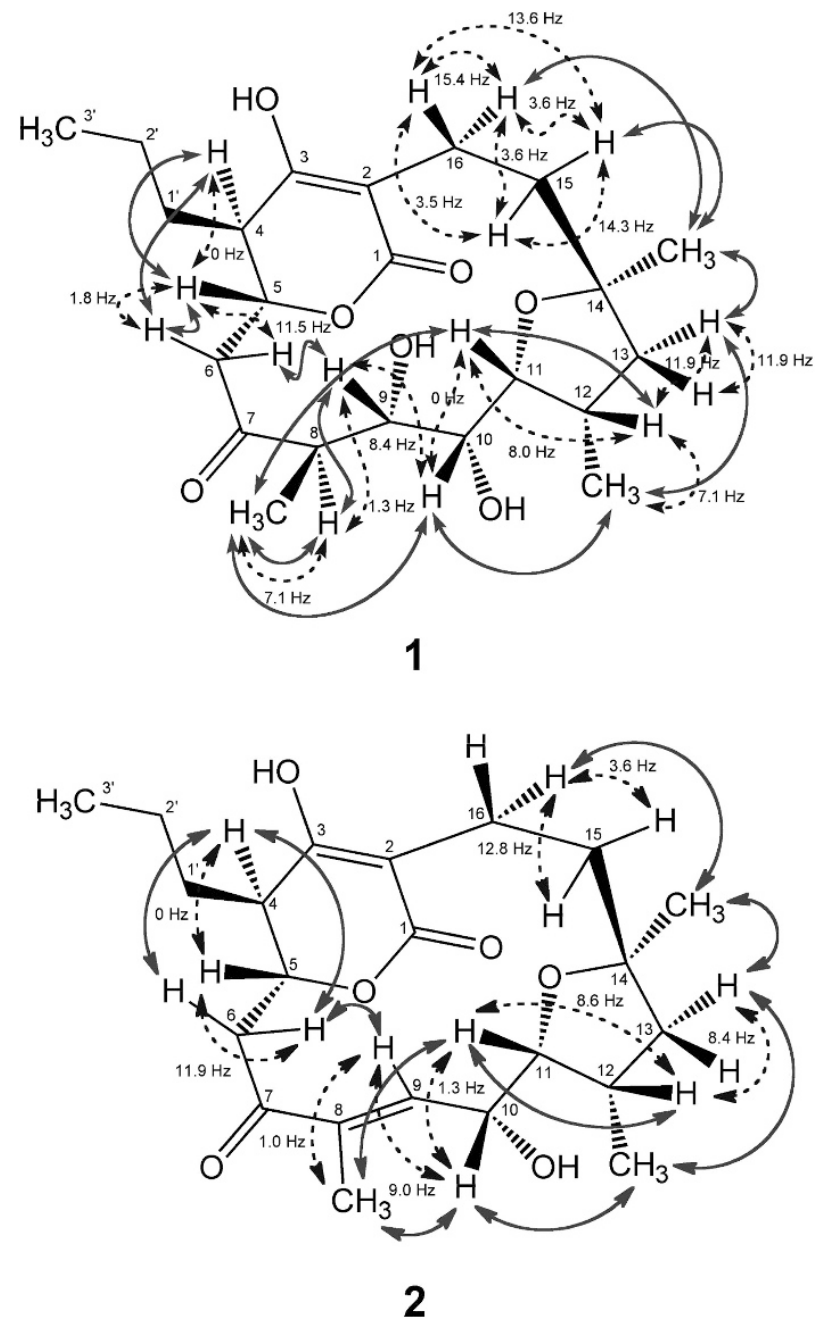

Figure $\mathbf{3}$ Key NOE or ROESY correlations (arrow line) and coupling constants (arrow dot) of mangromicins A (1) and B (2). 


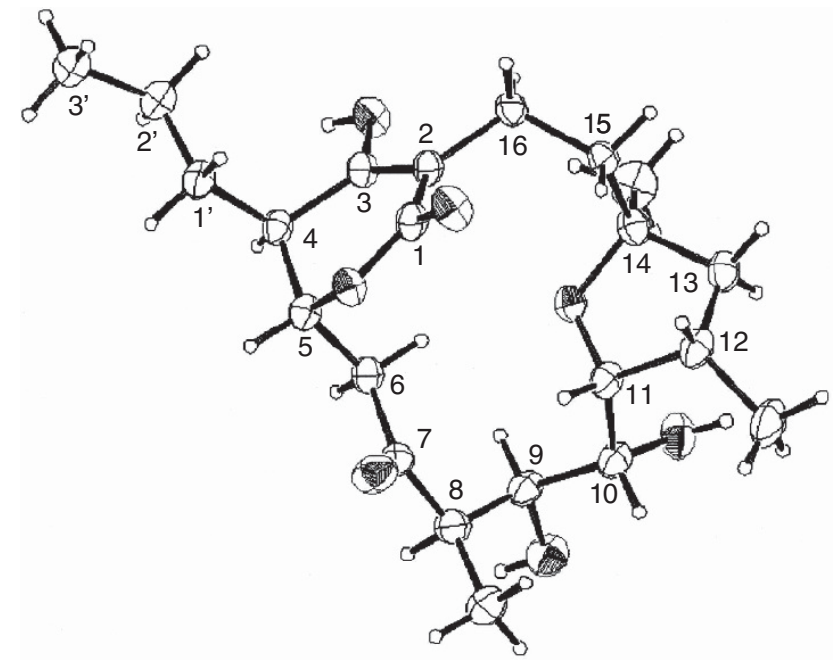

Figure 4 ORTEP (Oak Ridge Thermal-Ellipsoid Plot Program) plot of mangromicin A (1) with the displacement ellipsoids drawn at the $50 \%$ probability level.

\section{Structure elucidation of mangromicin B (2)}

Mangromicin B (2) was obtained as a pale yellow powder that was determined to have the molecular formula of $\mathrm{C}_{22} \mathrm{H}_{32} \mathrm{O}_{6}$ by HR-ESIMS $[\mathrm{M}+\mathrm{H}]^{+} \mathrm{m} / z 393.2271$ (calcd. for $\mathrm{C}_{22} \mathrm{H}_{33} \mathrm{O}_{6}, 393.2277$ ). This result indicated that 2 had lost one oxygen atom and two hydrogen atoms from 1 , and the ${ }^{1} \mathrm{H}$ and ${ }^{13} \mathrm{C}$ NMR spectra of 2 showed that they are highly analogous to those of 1 with a cyclopentadecane ring. The ${ }^{1} \mathrm{H}$ and ${ }^{13} \mathrm{C}$ NMR spectra of 2 in $\mathrm{CD}_{3} \mathrm{OD}$ could be obtained with dissolved and sharp signals.

The ${ }^{1} \mathrm{H}$ and ${ }^{13} \mathrm{C}$ NMR spectral data of 2 are listed in Table 3. The ${ }^{1} \mathrm{H}$ NMR data indicated the presence of three oxygenated $s p^{3}$ methines, one olefinic proton, two $s p^{3}$ methine protons containing one methine coupled to one methyl group, six methylenes, one primary methyl, one secondary methyl and two tertiary methyls. The ${ }^{13} \mathrm{C}$ NMR spectrum showed the resonances of 22 carbons, which were classified into four olefinic carbons, two carbonyl carbons at $\delta_{\mathrm{c}} 168.4$ and 205.2, one oxygenated $s p^{3}$ quaternary carbon, three oxygenated $s p^{3}$ methine carbons, two $s p^{3}$ methine carbons, six $s p^{3}$ methylene carbons and four methyl carbons by HSQC spectrum. The ${ }^{1} \mathrm{H}-{ }^{1} \mathrm{H}$ COSY of 2 indicated the presence of four partial structures: (a) C-5/C6; (b) C-8/C-13, C-8/C-8-Me, C-12/C-12-Me; (c) C-15/C-16; and (d) $\mathrm{C}-4 / \mathrm{C}-3^{\prime}$ as shown in Figure 2.

Analysis of HMBC spectra confirmed the presence of a 5,6-dihydro-4-hydroxy-2-pyrone moiety as shown in Figure 2. In addition, the presence of hydroxy group at C-3 position was also determined by hydrogen-deuterium (H/D) exchange experiment in $2 .^{21}$ The $\delta_{c}$ value of C-3 was shifted from 167.386 to 168.497 and the value of $\Delta \delta$ was -1.1 p.p.m. $\left(\Delta \delta=\delta_{\mathrm{C}}\right.$ (p.p.m.) in $\mathrm{CD}_{3} \mathrm{OD}-\delta_{\mathrm{C}}$ (p.p.m.) in $\mathrm{CD}_{3} \mathrm{OH}$ ) (Supplementary Table S1). This result suggested that a hydroxy group is connected to the C-3 position. In addition, tetrahydrofuran unit was deduced from the comparison of chemical shifts with 1 (C-11 at $\delta_{\mathrm{c}} 80.3$ and $\mathrm{H}-11$ at $\delta_{\mathrm{H}}$ 3.19, C-14 at $\delta_{\mathrm{c}} 85.0$ in $1 ; \mathrm{C}-11$ at $\delta_{\mathrm{c}} 84.4$ and $\mathrm{H}-11$ at $\delta_{\mathrm{H}} 3.68, \mathrm{C}-14$ at $\delta_{\mathrm{c}} 82.3$ in 2 ).

In comparison of chemical shifts of 2 with $\mathbf{1}$, one olefin proton at $\delta_{\mathrm{H}} 6.74(\mathrm{H}-9)$ instead of one methine proton $\delta_{\mathrm{H}} 2.75(\mathrm{H}-8)$ and one oxygenated methine proton at $\delta_{\mathrm{H}} 4.29(\mathrm{H}-9)$ of 1 and one tertiary methyl proton $\left(\delta_{\mathrm{H}} 1.76\right)$ instead of one secondary methyl proton $\left(\delta_{\mathrm{H}} 1.03\right)$ in 1 were confirmed in 2 . The HMBC correlations from
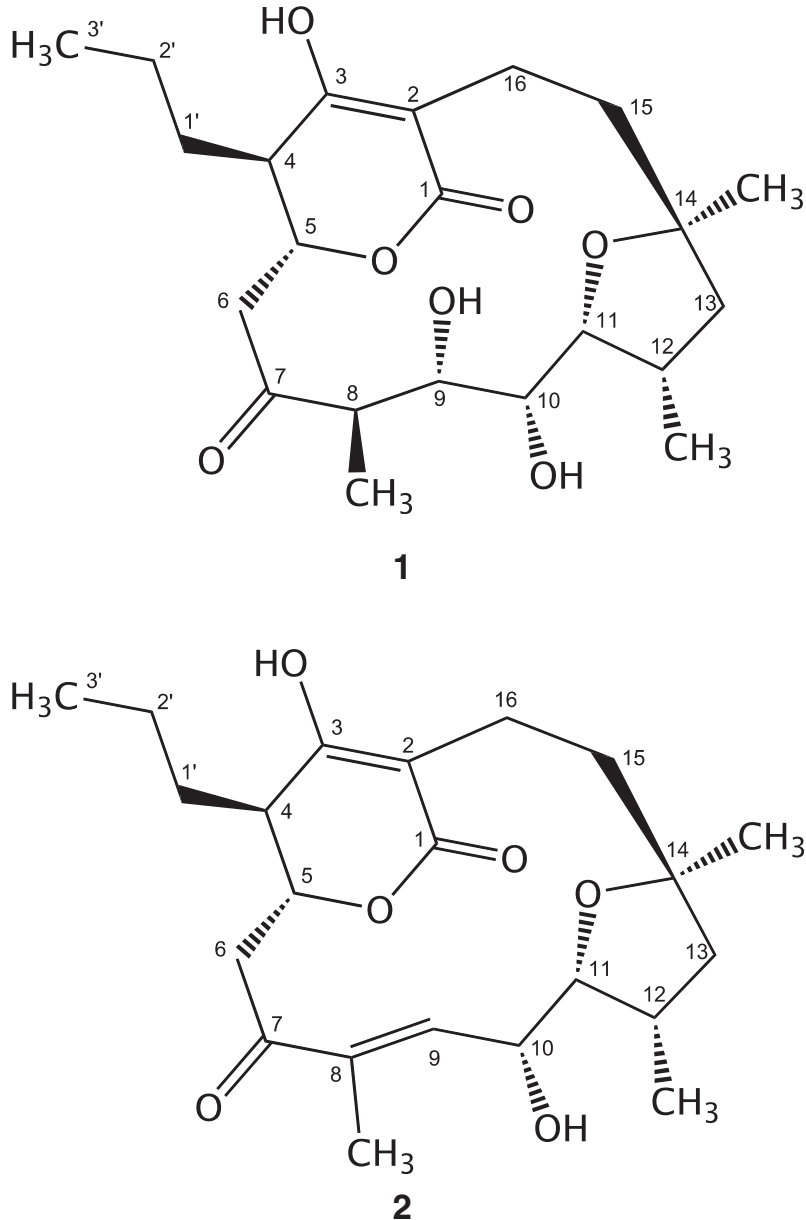

Figure 5 Relative configurations of mangromicins A (1) and B (2).

$\mathrm{H}_{2}-6$ to C-7, C-8 and C-9; from $\mathrm{H}_{3}-8-\mathrm{Me}$ to C-7, C-8 and C-9; and from $\mathrm{H}-10$ to $\mathrm{C}-8$ reveal that 2 have a trisubstituted olefin between C-8 and C-9. The trisubstituded olefin between C-8 and C-9 was found to have $E$ configuration by the ROESY correlations between $\mathrm{H}_{3}-8-\mathrm{Me}$ and $\mathrm{H}-10$, and $\mathrm{H}-6 \mathrm{~b}$ and $\mathrm{H}-9$ (Figure 3). Therefore, the planer structure of $\mathbf{2}$ was elucidated as shown in Figure 2, and it was designated as mangromicin $\mathrm{B}$.

The relative configuration of 2 was estimated by ${ }^{1} \mathrm{H}-{ }^{1} \mathrm{H}$ coupling constant analysis, differential NOE and ROESY experiments (Figure 3). The ROESY correlations in 2 were almost similar to those in 1. The ROESY correlations were observed between $\mathrm{H}-4 / \mathrm{H}_{2}-6$, $\mathrm{H}-6 \mathrm{~b} / \mathrm{H}-9, \mathrm{H}_{3}-8-\mathrm{Me} / \mathrm{H}-10, \mathrm{H}_{3}-8-\mathrm{Me} / \mathrm{H}-11, \mathrm{H}-10 / \mathrm{H}_{3}-12-\mathrm{Me}, \mathrm{H}_{3}-12-$ $\mathrm{Me} / \mathrm{H}-13 \mathrm{~b}$ and $\mathrm{H}-13 \mathrm{~b} / \mathrm{H}_{3}-14-\mathrm{Me}$, and $\mathrm{H}-14-\mathrm{Me} / \mathrm{H}-16 \mathrm{~b}$. In addition, the coupling constants were observed between $\mathrm{H}-9$ and $\mathrm{H}-10$ $(9.0 \mathrm{~Hz})$, and $\mathrm{H}-10$ and $\mathrm{H}-11(1.3 \mathrm{~Hz})$. A coupling between $\mathrm{H}-4$ and H-5 was not observed. These results suggested that 1 has the relative configuration of $4 R^{\star}, 5 R^{\star}, 10 R^{\star}, 11 R^{\star}, 12 S^{\star}$ and $14 S^{\star}$ (Figure 5).

Owing to the difficulties in determining the absolute stereochemistry of 2 by crystallization, efforts were focused toward chemical methods, notably the modified Mosher method. ${ }^{22-25}$ Subsequent interpretation of $\Delta \delta_{S-R}$ values for the $\alpha$-methoxy- $\alpha$ trifluoromethylphenylacetate (MTPA) derivative ((R)-MTPA ester, HR-ESI-MS $[\mathrm{M}+\mathrm{H}]^{+} m / z$ 609.2699; (S)-MTPA ester, HR-ESI-MS $[\mathrm{M}+\mathrm{H}]^{+} \mathrm{m} / \mathrm{z}$ 609.2667; calcd. for $\mathrm{C}_{32} \mathrm{H}_{39} \mathrm{~F}_{3} \mathrm{O}_{8}, \mathrm{~m} / z$ 609.2675) 
Table 3 NMR spectroscopic data $\left(\mathrm{CD}_{3} \mathrm{OD}, 400 \mathrm{MHz}\right)$ for mangromicin $\mathrm{B}$ (2)

\begin{tabular}{|c|c|c|c|}
\hline Position & $\delta_{C}$, mult & $\delta_{H}$ (int., mult., $J$ in $\mathrm{Hz}$ ) & $H M B C$ \\
\hline 2 & 104.0, C & & \\
\hline 4 & $43.5, \mathrm{CH}$ & $2.29(1 \mathrm{H}, \mathrm{dd}, 7.6,5.2)$ & $\mathrm{C}-2, \mathrm{C}-3, \mathrm{C}-5, \mathrm{C}-6, \mathrm{C}-1^{\prime}, \mathrm{C}-2^{\prime}$ \\
\hline 5 & $78.3, \mathrm{CH}$ & $4.62(1 \mathrm{H}, \mathrm{dd}, 11.9,4.8)$ & C-1, C-3, C-4, C-7, C-1' \\
\hline $6 a$ & $43.3, \mathrm{CH}_{2}$ & $2.18(1 \mathrm{H}, \mathrm{dd}, 11.7,4.8)$ & $\mathrm{C}-4, \mathrm{C}-5, \mathrm{C}-7, \mathrm{C}-8,(\mathrm{C}-9)$ \\
\hline 8 & $134.8, \mathrm{C}$ & & \\
\hline 9 & $150.7, \mathrm{CH}$ & $6.74(1 \mathrm{H}, \mathrm{dq}, 9.0,1.0)$ & \\
\hline 10 & $69.9, \mathrm{CH}$ & $4.54(1 \mathrm{H}, \mathrm{dd}, 9.0,1.3)$ & C-8 \\
\hline 11 & $84.4, \mathrm{CH}$ & $3.68(1 \mathrm{H}, \mathrm{dd}, 8.6,1.3)$ & $\mathrm{C}-9, \mathrm{C}-10, \mathrm{C}-12, \mathrm{C}-13, \mathrm{C}-12-\mathrm{Me}$ \\
\hline 12 & $37.3, \mathrm{CH}$ & $2.53(1 \mathrm{H}, \mathrm{m})$ & \\
\hline $13 a$ & $50.4, \mathrm{CH}_{2}$ & $1.41(1 \mathrm{H}, \mathrm{dd}, 12.0,8.4)$ & C-11, C-12, C-14, C-15, C-12-Me, C-14-Me \\
\hline $16 a$ & 20.1, $\mathrm{CH}_{2}$ & $2.05(1 \mathrm{H}, \mathrm{ddd}, 15.2,4.4,3.5)$ & C-1, C-2, C-3, C-14, C-15 \\
\hline $16 b$ & & $2.91(1 \mathrm{H}, \mathrm{ddd}, 15.2,12.8,3.6)$ & \\
\hline $1^{\prime} \mathrm{a}$ & $36.4, \mathrm{CH}_{2}$ & $1.56(1 \mathrm{H}, \mathrm{m})$ & $\mathrm{C}-3, \mathrm{C}-4, \mathrm{C}-5, \mathrm{C}-2^{\prime}, \mathrm{C}-3^{\prime}$ \\
\hline $1^{\prime} \mathrm{b}$ & & $1.60(1 \mathrm{H}, \mathrm{m})$ & \\
\hline $2^{\prime} \mathrm{a}$ & $20.7, \mathrm{CH}_{2}$ & $1.36(1 \mathrm{H}, \mathrm{m})$ & \\
\hline $2^{\prime} \mathrm{b}$ & & $1.43(1 \mathrm{H}, \mathrm{m})$ & \\
\hline $3^{\prime}(\mathrm{Me})$ & $14.4, \mathrm{CH}_{3}$ & $0.94(3 \mathrm{H}, \mathrm{t}, 7.4)$ & $C-1^{\prime}, \mathrm{C}-2^{\prime}$ \\
\hline 8-Me & $11.7, \mathrm{CH}_{3}$ & $1.76(3 \mathrm{H}, \mathrm{d}, 1.0)$ & C-7, C-8, C-9 \\
\hline 12-Me & $16.5, \mathrm{CH}_{3}$ & $1.23(3 \mathrm{H}, \mathrm{d}, 6.8)$ & C-11, C-12, C-13 \\
\hline 14-Me & $24.9, \mathrm{CH}_{3}$ & $1.37(3 \mathrm{H}, \mathrm{s})$ & C-13, C-14, C-15 \\
\hline
\end{tabular}

averlapped. Bracket means ${ }^{4} \mathrm{~J}$ coupling.

Table 4 Antitrypanosomal activity of mangromicins A (1) and B (2)

\begin{tabular}{|c|c|c|c|}
\hline \multirow[b]{2}{*}{ Compound } & \multicolumn{2}{|c|}{$I_{50}\left(\mu \mathrm{gm} I^{-1}\right)$} & \multirow[b]{2}{*}{$S I^{a}$} \\
\hline & Antitrypanosomal activity ${ }^{b}$ & Cytotoxicityc & \\
\hline Mangromicin A & 2.44 & 16.02 & 6.6 \\
\hline Mangromicin B & 43.39 & 92.60 & 2.1 \\
\hline Suramin ${ }^{d}$ & 1.58 & $>100$ & $>63$ \\
\hline Eflornithine $^{d}$ & 2.27 & $>100$ & $>44$ \\
\hline
\end{tabular}

a Selectivity index $(\mathrm{SI})=I \mathrm{C}_{50}$ value of cytotoxicity $/ I \mathrm{C}_{50}$ value of antitrypanosomal activity. $\mathrm{b}$ In vitro antitrypanosomal activity against Trypanosoma brucei brucei GUTat 3.1.

${ }^{\text {cC}}$ ytotoxicity in MRC- 5 cells.

${ }^{d}$ Clinical antitrypanosomal drug.

yielded unreliable results. The $\Delta \delta_{S-\mathrm{R}}$ values at $\mathrm{H}-9, \mathrm{H}_{3}-12-\mathrm{Me}$ and $\mathrm{H}_{3}$-14-Me showed $-0.19,0.31$ and -0.38 , respectively. Therefore, the absolute configuration of 2 could not be determined by the modified Mosher's method (Supplementary Figure S2).

The unusual chemical shift values of H-6b in 1 (4.54 p.p.m.) and 2 (4.03 p.p.m.) were observed. Although it remains unclear, it was suggested that the observed chemical shift values might be due to the magnetic anisotropy effects of a 5,6-dihydro-4-hydroxy-2-pyrone moiety and a carbonyl group at C-7.

To our knowledge, mangromicins A (1) and B (2) are first natural products, which is an unprecedented structural skeleton of a cyclopentadecane with a tetrahydrofuran unit and a 5,6-dihydro-4hydroxy-2-pyrone moiety.
Biological activities of mangromicins A (1) and B (2)

Mangromicins A and B were evaluated in a panel of assays, such as antimicrobial activities for pathogenic bacteria and fungi, antiviral activity, cancer cell cytotoxicity and antiparasitic activity for parasitic protozoan. In consequence, mangromicins $\mathrm{A}$ and $\mathrm{B}$ exhibited antitrypanosomal activities. As shown in Table 4, mangromicin A (1) showed potent activity against Trypanosoma brucei brucei GUTat 3.1 strain $\left(\mathrm{IC}_{50}=2.4 \mu \mathrm{g} \mathrm{ml}^{-1}\right)$, similar to that of the clinically used antitrypanosomal drugs, suramin and eflornithine. However, 1 exhibited more potent cytotoxicity against MRC- 5 cells than both suramin and eflornithine. Mangromicin B (2) showed less potent antitrypanosomal and cytotoxic properties compared with $\mathbf{1}$ $\left(\mathrm{IC}_{50}=43.4 \mu \mathrm{g} \mathrm{ml}^{-1}\right)$. Therefore, the hydroxy group at C-9 position may have an important role to exert the antitrypanosomal and cytotoxic activities of the mangromicins.

\section{METHODS}

\section{General experimental procedures}

NMR spectra were measured using a Varian XL-400 and INOVA 600 (Varian, Palo Alto, CA, USA) or JEOL JNM-ECA 500 spectrometer (JEOL, Tokyo, Japan), with ${ }^{1} \mathrm{H}-\mathrm{NMR}$ at 400,500 or $600 \mathrm{MHz}$ and ${ }^{13} \mathrm{C}-\mathrm{NMR}$ at 100,125 or $150 \mathrm{MHz}$ in $\mathrm{CD}_{3} \mathrm{OD}$ or DMSO- $d_{6}$. The chemical shifts are expressed in p.p.m. and are referenced to residual $\mathrm{CD}_{3} \mathrm{OD}$ (3.31 p.p.m.) or DMSO- $d_{6}$ (2.48 p.p.m.) in the ${ }^{1} \mathrm{H}-\mathrm{NMR}$ spectra and $\mathrm{CD}_{3} \mathrm{OD}$ (49 p.p.m.) or DMSO- $d_{6}$ (39.5 p.p.m.) in the ${ }^{13} \mathrm{C}-\mathrm{NMR}$ spectra. In the $\mathrm{H} / \mathrm{D}$ exchange experiment, ${ }^{13} \mathrm{C}$ NMR spectra were measured in $\mathrm{CD}_{3} \mathrm{OH}$. 
LC-ESI-MS spectra were measured using an AB Sciex QSTAR Hybrid LC/MS/MS Systems (AB Sciex, Framingham, MA, USA). IR spectra $(\mathrm{KBr})$ were taken on a Horiba FT-710 Fourier transform IR spectrometer (Horiba Ltd, Kyoto, Japan). UV spectra were measured with a Hitachi U-2810 spectrophotometer (Hitachi, Tokyo, Japan). Optical rotation was measured on a JASCO model DIP-1000 polarimeter (Jasco, Tokyo, Japan).

\section{Taxonomic studies of strain K10-0216}

The International Streptomyces Project media recommended by Shiring and Gottlieb $^{26}$ and by Waksman ${ }^{27}$ were used to investigate cultural characteristics. Cultures were observed after incubation for 2 weeks at $27^{\circ} \mathrm{C}$. The morphological characteristics were observed by scanning electron microscope (JSM-5600; JEOL) after incubation on inorganic salts-starch agar for 4 weeks at $27^{\circ} \mathrm{C}$ and fixation with $4 \%$ osmium tetroxide vapor. Isomers of diaminopimelic acid in whole-cell hydrolysates were determined by TLC, following the standard methods of Becker et al. ${ }^{28}$ and Hasegawa et al. ${ }^{29}$ Menaquinones were extracted and purified by the method of Collins et al..$^{30}$ and then analyzed by LC/MS (JSM-T 100LP; JEOL) with a CAPCELL PAK C18 column (Shiseido, Tokyo, Japan) eluted with methanol/2-propanol (7:3). 16S rRNA gene sequence was amplified by PCR and sequenced on a 3130 Genetic Analyzer (Applied Biosystems, Carlsbad, CA, USA) using a BigDye Terminator v.3.1 cycle sequencing kit (Applied Biosystems) according to the manufacturer's instructions.

\section{Fermentation}

The strain K10-0216 was grown and maintained on agar slants, consisting of $1.0 \%$ starch, $0.3 \% \mathrm{NZ}$ amine, $0.1 \%$ yeast extract, $0.1 \%$ meat extract, $1.2 \%$ agar and $0.3 \% \mathrm{CaCO}_{3}$. A loop of spores of strain $\mathrm{K} 10-0216$ was inoculated into $100 \mathrm{ml}$ of the seed medium, consisting of $2.4 \%$ starch, $0.1 \%$ glucose, $0.3 \%$ peptone, $0.3 \%$ meat extract, $0.5 \%$ yeast extract and $0.4 \% \mathrm{CaCO}_{3}$ (adjusted to pH 7.0 before sterilization) in a $500-\mathrm{ml}$ Erlenmeyer flask. The flask was incubated on a rotary shaker $(210$ r.p.m. $)$ at $27^{\circ} \mathrm{C}$ for 3 days. A 1-ml portion of the seed culture was transferred to 500-ml Erlenmeyer flasks (total 150) containing $100 \mathrm{ml}$ of starch medium, consisting of $2 \%$ soluble starch, $0.5 \%$ glycerol, $1.0 \%$ defatted wheat germ, $0.3 \%$ meat extract, $0.3 \%$ dry yeast and $0.3 \% \mathrm{CaCO}_{3}$ (adjusted to $\mathrm{pH} 7.0$ before sterilization) and fermentation was carried out on a rotary shaker $\left(210\right.$ r.p.m.) at $27^{\circ} \mathrm{C}$ for 7 days.

\section{Esterification of mangromicin B (2) with MTPA chloride}

To $1.0 \mathrm{mg}$ of 2 was added $200 \mu \mathrm{l}$ of anhydrous dichloromethane and $200 \mu \mathrm{l}$ of anhydrous pyridine, followed by $50 \mu \mathrm{l}$ of $(R)$ - or $(S)$-MTPA chloride. The mixture was stirred for $16 \mathrm{~h}$ at room temperature. $\mathrm{MeOH}$ was added to the mixture for quenching. The organic solvents were removed in vacuo and $400 \mu \mathrm{l}$ of $\mathrm{H}_{2} \mathrm{O}$ and $1.2 \mathrm{ml}$ of AcOEt were then added. The AcOEt layer was concentrated in vacuo and the respective $(R)$ - or $(S)$-MTPA esters of 2 were independently purified by HPLC, using a semiprep column $\left(\mathrm{C}_{18}(5 \mu \mathrm{m}\right.$ : $10 \times 250 \mathrm{~mm})$ ) with isocratic $\left(75 \% \mathrm{CH}_{3} \mathrm{CN}\right.$ in $\left.\mathrm{H}_{2} \mathrm{O}\right)$ conditions for $40 \mathrm{~min}$.

\section{Crystallization method}

Approximately $5.0 \mathrm{mg}$ of $\mathbf{1}$ or $\mathbf{2}$ was placed in a polyspring glass insert with $10 \mu \mathrm{l}$ of $\mathrm{MeOH}$ and $30 \mu \mathrm{l}$ of $\mathrm{H}_{2} \mathrm{O}$ and sealed inside an amber vial. The septum of the vial was pierced with a needle and the solution was evaporated for $16 \mathrm{~h}$ at $25^{\circ} \mathrm{C}$. Although a crystal of $\mathbf{1}$ was able to be evaluated with X-ray analysis, the crystal of $\mathbf{2}$ was of insufficient quality to allow examination using X-ray analysis.

\section{X-ray crystallographic analysis of mangromicin A (1)}

A colorless needle crystal of 1 was obtained from $\mathrm{MeOH}$ and $\mathrm{H}_{2} \mathrm{O}$. All measurements were made on a Rigaku-AXIS-Rapid II diffractometer (Rigaku, Tokyo, Japan) using graphite monochromated $\mathrm{Cu}-\mathrm{Ka}$ radiation $(\lambda=1.54184$ $\AA$ ). The data were collected at $23^{\circ} \mathrm{C}$. The structure was solved by direct methods (SHELXS-97) and refined by full-matrix least-squares on $\mathrm{F}^{2}$. All nonhydrogen atoms were refined anisotropically. Hydrogen atoms were placed in ideal positions and refined using the riding model. Crystallographic data have been deposited in the Cambridge Crystallographic Data Center (Cambridge, UK) with the deposition number CCDC 947034. Copies of the data can be obtained, free of charge, on application to the Director, CCDC, 12 Union Road, Cambridge CB2 1EZ, UK (e-mail: deposit@ccdc.cam.ac.uk). Detailed crystallographic information for mangromicin A is provided in the Supporting Information (CIF). The crystal data were monoclinic, space group $\mathrm{P}_{1}$, $a=12.8526(6) \AA, \quad b=13.1817(5) \AA, \quad c=13.4389(5) \AA, \quad b=93.159(2)^{\circ}$, $V=2273.3(2) \AA^{3}$ and $Z=4$.

\section{Antitrypanosomal activity in vitro}

In vitro antitrypanosomal activities against T. brucei brucei strain GUTat 3.1 were measured, using the method described previously. ${ }^{31}$ In brief, the strain GUTat 3.1 was cultured in Iscove's modified Dulbecco's media with various supplements and $10 \%$ heat-inactivated fetal bovine serum at $37^{\circ} \mathrm{C}$, under $5.0 \% \mathrm{CO}_{2}-95 \%$ air. Subsequently, $95 \mu \mathrm{l}$ of the trypanosome suspension $(2.0$ $2.5 \times 10^{4}$ trypanosomes per $\mathrm{ml}$ ) was transferred into a 96-well microtiter plate and $5.0 \mu \mathrm{l}$ of a test compound solution (dissolved in 5.0\% DMSO) was added and the plate incubated for $72 \mathrm{~h}$ at $37^{\circ} \mathrm{C}$ (long incubation-low inoculation test). Subsequently, $10 \mu \mathrm{l}$ of the fluorescent dye Alamar Blue was added to each well. After incubation for 3-6h, the resulting solution was read at 528/20 nm excitation wavelengths and 590/30 nm emission wavelengths using an FLx800 fluorescence microplate reader (BioTek Instruments, Winooski, VT, USA). The $\mathrm{IC}_{50}$ values were determined using the fluorescent plate reader software (KC-4; BioTek Instruments). Successive subcultures were carried out in 24-well tissue culture plates under the same conditions.

\section{Cytotoxic activity in vitro}

Measurement of cytotoxic activity against human fetal lung fibroblast MRC-5 cells was carried out as described previously. ${ }^{32}$

\section{ACKNOWLEDGEMENTS}

This study was supported, in part, by funds from Quality Assurance Framework of Higher Education from the Ministry of Education, Culture, Sports, Science and Technology (MEXT), Japan and the institute for Fermentation (IFO), Osaka, Japan. We are grateful to Ms Noriko Sato, School of Pharmacy, Kitasato University, for measurements of NMR spectra, Ms Miyuki Namatame and Dr Tomoyasu Hirose, Kitasato Institute for Life Sciences, Kitasato University, for antitrypanosomal and cytotoxic assay and advice on the structure, respectively.

1 Newman, D. J. \& Cragg, G. M. Natural products as sources of new drugs over the 30 years from 1981 to 2010. J. Nat. Prod. 75, 311-335 (2012).

2 Bérdy, J. Bioactive microbial metabolites. J. Antibiot. 58, 1-26 (2005).

3 Chin, Y. W., Balunas, M. J., Chai, H. B. \& Kinghorn, A. D. Drug discovery from natural sources. AAPS J. 8, E239-E253 (2006).

4 Peano, C. et al. Comparative genomics and transcriptional profiles of Saccharopolyspora erythraea NRRL 2338 and a classically improved erythromycin over-producing strain. Microb. Cell Fact. 11, 32 (2012).

5 Bentley, S. D. et al. Complete genome sequence of the model actinomycete Streptomyces coelicolor A3(2). Nature 417, 141-147 (2002).

6 Omura, S. et al. Genome sequence of an industrial microorganism Streptomyces avermitilis: deducing the ability of producing secondary metabolites. Proc. Natl Acad. Sci. USA 98, 12215-12220 (2001).

7 Ohnishi, Y. et al. Genome sequence of the streptomycin-producing microorganism Streptomyces griseus IFO 13350. J. Bacteriol. 190, 4050-4060 (2008).

8 Flärdh, K. \& Buttner, M. J. Streptomyces morphogenetics: dissecting differentiation in a filamentous bacterium. Nat. Rev. Microbiol. 7, 36-49 (2009).

9 Scherlach, K. \& Hertweck, C. Triggering cryptic natural product biosynthesis in microorganisms. Org. Biomol. Chem. 7, 1753-1760 (2009).

$10 \mathrm{Li}, \mathrm{J}$. W. \& Vederas, J. C. Drug discovery and natural products: end of an era or an endless frontier? Science 325, 161-165 (2009).

11 Ōmura, S. et al. A new alkaloid AM-2282 of Streptomyces origin. Taxonomy, fermentation, isolation and preliminary characterization. J. Antibiot. 30, 275-282 (1977).

$12 \mathrm{Xie}, \mathrm{Q}$. et al. Description of Lentzea flaviverrucosa sp. nov. and transfer of the type strain of Saccharothrix aerocolonigenes subsp. staurosporea to Lentzea albida. Int. J. Syst. Evol. Microbiol. 52, 1815-1820 (2002).

13 Takahashi, Y., Shinose, M., Seino, A., Iwai, Y. \& Ōmura, S. Transfer of staurosporineproducing strain Streptomyces staurosporeus AM-2282 to the genus Saccharothrix as Saccharothrix aerocolonigenes (Labeda 1986) subsp. Actinomycetologica 9, 19-26 (1995).

14 Tamaoki, T. et al. Staurosporine, a potent inhibitor of phospholipid/Ca ${ }^{++}$dependent protein kinase. Biochem. Biophys. Res. Commun. 135, 397-402 (1986).

15 Ōmura, S., Sasaki, Y., Iwai., Y. \& Takeshima, H. Staurosporine, a potentially important gift from a microorganism. J. Antibiot. 48, 535-548 (1995). 
16 Capdeville, R., Buchdunger, E., Zimmermann, J. \& Matter, A. Glivec (STI571, imatinib), a rationally developed, targeted anticancer drug. Nat. Rev. Drug Discov. 1, 493-502 (2002).

17 Nakano, H. \& Ōmura, S. Chemical biology of natural indolocarbazole products: 30 years since the discovery of staurosporine. J. Antibiot. 62, 17-26 (2009).

18 Kamiya, Y. et al. in Abstract of the 2013 Annual Meeting of the Society for Actinomycetes Japan. The Society for Actinomycetes Japan, Hiroshima, Japan, pp 75 (2013).

19 Ōmura, S et al. (The Kitasato Institute). Novel Mangromicin Compound and Production Method Therefore. WO 2013031239 (7 March 2013).

20 Labeda, D. P. et al. Revival of the genus Lentzea and proposal for Lechevalieria gen. nov. Int. J. Syst. Evol. Microbiol. 51, 1045-1050 (2001).

21 Smirnov, S. N. et al. Hydrogen/deuterium isotope effects on the NMR chemical shifts and geometries of intermolecular low-barrier hydrogen-bonded complexes. J. Am. Chem. Soc. 118, 4094-4101 (1996).

22 Dale, J. A., Dull, D. L. \& Mosher, H. S. $\alpha$-Methoxy- $\alpha$-trifluoromethylphenylacetic acid, a versatile reagent for the determination of enantiomeric composition of alcohols and amines. J. Org. Chem. 34, 2543-2549 (1969).

23 Dale, J. A. \& Mosher, H. S. Nuclear magnetic resonance enantiomer regents Configurational correlations via nuclear magnetic resonance chemical shifts of diastereomeric mandelate, 0 -methylmandelate, and $\alpha$-methoxy- $\alpha$-trifluoromethylphenylacetate (MTPA) esters. J. Am. Chem. Soc. 95, 512-519 (1973).
24 Sullivan, G. R., Dale, J. A. \& Mosher, H. S. Correlation of configuration and fluorine-19 chemical shifts of $\alpha$-methoxy- $\alpha$-trifluoromethylphenyl acetate derivatives. J. Org. Chem. 38, 2143-2147 (1973).

25 Seco, J., Martino, M., Quinoa, E. \& Riguera, R. Absolute configuration of 1,n-diols by NMR: the importance of the combined anisotropic effects in bis-arylmethoxyacetates. Org. Lett. 2, 3261-3264 (2000).

26 Shiring, E. B. \& Gottlieb, D. Methods for characterization of Streptomyces species. Int J. Syst. Bacteriol. 16, 313-340 (1966).

27 Waksman, S. A. (ed.) The Actinomycetes Vol. 2. Williams and Wilkins, Baltimore, MD (1961).

28 Becker, B., Lechevalier, M. P. \& Lechevalier, H. A. Chemical composition of cell-wall preparation from strains of various form-genera of aerobic actinomycetes. Appl. Microbiol. 13, 236-243 (1965).

29 Hasegawa, T., Takizawa, M. \& Tanida, S. A rapid analysis for chemical grouping of aerobic actinomycetes. J. Gen. Appl. Microbiol 29, 319-322 (1983).

30 Collins, M. D., Goodfellow, M. \& Minnikin, D. E. Distribution of menaquinones in actinomycetes and corynebacteria. J. Gen. Microbiol. 100, 221-230 (1977).

31 Otoguro, K. et al. Selective and potent in vitro antitrypanosomal activities of ten microbial metabolites. J. Antibiot. 61, 372-378 (2008).

32 Otoguro, K. et al. Potent antimalarial activities of polyether antibiotic, X-206. J. Antibiot. 54, 658-663 (2001).

Supplementary Information accompanies the paper on The Journal of Antibiotics website (http://www.nature.com/ja) 